DOI: $10.31866 / 2410-1915.21 .2020 .208251$

UDC 378.016:81’243]:316.77

\title{
INTERACTION OF LANGUAGE AND CULTURE IN THE PROCESS OF FOREIGN LANGUAGE STUDYING AT HIGHER EDUCATION ESTABLISHMENTS
}

\author{
Nataliia Sarnovska
}

Lecturer, ORCID:0000-0001-7278-5183,nat_sarnovskaya@ukr.net, Kyiv National University of Culture and Arts, 36, Ye. Konovaltsia St., Kyiv, 01133, Ukraine

\section{For citations:}

Sarnovska, N. (2020). Interaction of Language and Culture in the Process of Foreign Language Studying at Higher Education Establishments. Culture and Arts in the Modern World, 21, 160-171. https:// doi.org/10.31866/2410-1915.21.2020.208251.

The purpose of the article is to examine and demonstrate some features of a foreign language studying as a means of intercultural communication, to prove that for effective communication in a foreign language it is necessary not only to possess this language at a sufficient level but also to be familiar with the culture of its native speakers. Professional competence of the new formation specialists requires having the knowledge, abilities, skills for the establishment of dialogue and mutual understanding with foreign partners at a high professional level, and thus the establishment of dialogue between cultures; tolerant attitude towards linguistic and cultural differences interlocutor, a misunderstanding that cannot be avoided time of communication with representatives of another culture. The research methodology includes study, analysis and generalisation with the purpose to demonstrate the evidence of an inextricable link of culture and language in the study of foreign languages. The scientific novelty is to show new features of English as a foreign language, because new technologies, modern methods of communication, slang, global problems, global culture, other foreign languages lead to lexicalsemantic changes in the vocabulary of the language and its completion, as evidenced by the examples from the media given in the article; demonstrate key concepts of cultural literacy and consider some theoretical and practical issues related to improving cultural literacy in learning foreign languages. In the work, the author believes that when studying a foreign language, it is necessary to pay special attention to the characteristic features of modern vocabulary related to the increasing role of the Internet and other information technologies, and offers methods for developing communicative competence, taking into account the development of intercultural communication. Conclusions. The work proves that fluency in a foreign language is not achieved thanks to the knowledge of grammar, vocabulary, pronunciation skills or the ability to translate, but through foreign culture cognition. In the process of teaching, the focus is on the need to practice the use of a foreign language as a means of intercultural communication. The process of foreign languages teaching should be reviewed and optimised, taking into account trends in the development of intercultural communication in a multicultural world.

Keywords: foreign language learning; foreign language at university; English; language; culture; cultural literacy; intercultural communication.

(C) Nataliia Sarnovska, 2020 


\section{Introduction}

"Globalisation has made intercultural communication inevitable. Communicating with other cultures characterises today's business, classroom, and community. Hence, the art of knowing how to communicate with other cultures should be a workplace skill that is emphasised" (Gitimu, 2005). The rapid development of modern technologies, technical means and capabilities pose new challenges in the system of higher professional education. Among these, one can single out the expansion of specialities and specialisations in vocational training, the development of partnerships between universities, the opportunity to take internships abroad, and to listen to special lecture courses in various specialities. The problem of intercultural communication in this regard is of particular relevance. The specificity and complexity of the issues arising from this are since this communication is carried out in conditions of mismatch of national and cultural stereotypes of thinking and behaviour. Successful intercultural professional communication involves, along with knowledge of a foreign language, the ability to perceive and adequately interpret forms of communicative behaviour in all their diversity. The contemporary picture of the world is the interpenetration of cultures as a result of globalisation and integration processes that greatly influence and change the system of establishing international relations and their structure. The tendency for the adaptation of the modern man to fleeting processes in all spheres of life implies integration into the space of cultures unity, where the influence of culture on the consciousness and thinking of the person is inevitable. It directly influences the formation of the linguistic picture of the world, "which is a global image of the world, a reflection in the mind of man that created as a result of diverse experiences and spiritual experiences activities of man and the whole nation" (Holubenko, 2015, pp. 18-19) or as a particular way of perceiving the world of every civilisation, social systems (Maslova, 2004, p. 68).

The need to improve the quality of professional language training of specialists in a non-linguistic university is obvious. A modern specialist will be in demand due to the professional training, knowledge and skills acquired in the process of studying at a higher educational institution. Researchers understand the professional readiness of a future specialist to work in a multicultural space as a result of the process of improving his skills in the field of intercultural communication through a business and professional foreign language. The foreign language competence of the future specialist is an integral part of his professional culture. Knowledge of the language characteristics of the business and professional communication, the ability to establish business contacts, conduct business communication and cooperation reflect the essence of communicative foreign language competence and its main components: linguistic, pragmatic, sociocultural, discursive and intercultural competencies necessary for mastering business and professional foreign languages. Formation of these competencies the specialist becomes an important component of his successful employment and further career growth.

Just as an individual cannot naturally exist in isolation from other people, so no culture can fully function in isolation from the cultural achievements of 
other peoples. In the process of their life activity, they are forced to constantly turn to either their past or the experience of other cultures. At present, there are practically no cultural communities completely isolated from the world, except for small indigenous tribes lost in the most secluded corners of the planet. Today, a natural situation is when any people are open to the perception of others' cultural experiences. At the same time, they are ready to share their own culture with other peoples. This appeal to the cultures of other nations was called the "interaction of cultures" or "intercultural communication". As a rule, these concepts are considered as synonyms, although they have some specifics.

Professional competence of the new formation specialists requires having the knowledge, abilities, skills for the establishment of dialogue and mutual understanding with foreign partners at a high professional level, and thus the establishment of dialogue between cultures; tolerant attitude towards linguistic and cultural differences interlocutor, a misunderstanding that cannot be avoided time of communication with representatives of another culture.

The problem of intercultural communication is of significant interest to domestic and foreign experts, representatives of various scientific schools. So, the conceptual analysis of the nature, content, characteristics, and manifestations of intercultural communication presents in T. Grushevich, P. Donets, J. Lean, N. Larina,

A. Sadokhin, S. Ter-Minasova, L. Kulikova. The problem of communicative complications and misunderstandings among members different cultures and ways of overcoming them are research A. Virzhbitska, V. Hudikunst, N. Larina, V. Manakin, G. Triandis, E. Hall, G. Hofstede.

The problem of tolerance in the framework of intercultural communication revealed in the writings of N. Zakharchuk, L. Znykina, A. P. Sadokhin, V. Safonova, S. Ter-Minasova.

The works of L. Berberet, I. Mikhailenko, V. Turchenko and others are dedicated to the teaching of foreign languages as a means of intercultural communication in high educational establishments.

Studying and analysing the latest studies of the problem of intercultural communication, we note that most of the work focused on the identification and analysis of the concept of intercultural communication, its components, the interaction of culture and language, questions of cultural identity and differences; development and improvement of communicative competences and in general the coverage of theoretical aspects (F. Batsevych, N. Halytska, I. Dziuba, P. Donets, Miazova, L. Nagorna, A. Potebnia). While foreign experts (A. Moeller, Moore) propose practical recommendations for methods of teaching foreign languages, improving foreign language competence in the framework of intercultural communication based on analyses, opinion polls, analysis of the practical lessons' effectiveness on a given topic, and the like.

\section{Purpose of the article}

The purpose of the article is to show some features of a foreign language studying as a means of intercultural communication and substantiate that for 
effective communication in a foreign language it is necessary not only to possess this language at a sufficient level but also to be familiar with the culture of its native speakers. The success of teaching a foreign language depends on several factors. One of them is taking into account the national cultural specifics of a society in which the studied language is functioning. Understanding a foreign language text is impossible without understanding foreign cultural features associated with its creation. In today's global integration it is necessary not only to know foreign words but also to be familiar with the culture of other people because behind every word there is a part of the picture of another world, foreign and foreign culture. In the classroom, there is a need not only to pay attention to the relationship between language and culture but to teach a foreign language as an instrument of intercultural communication. This fact causes the relevance of the chosen topic.

\section{Main research material}

Culture can be defined as a set of habits shared by group members living in the same geographical area, biologically determined, such as communication tools (of which the language is basic), social relations at various levels, various types of everyday activities, products of this group and the way they are used, typical manifestations of personality, both at the national and individual levels and their ideas about their own place in the world. Scientists define culture as a type of worldview and a way of being in the human world, which shares these views with a particular community. Based on this concept of culture, intercultural competence could easily be connected in various contexts with the concept of modern society. While communicative competence lies in our ability to achieve spontaneous speech acts that are contextually appropriate, intercultural competence is our ability to manage events in the presence of interlocutors who have a different mindset and speak a different language. It even turns out to be impossible to learn it in the classroom using situational role-playing games, because we are talking about situations, in reality, implausible, where interculturalism does not appear in an unconscious form, as it happens in reality. In this sense, a teacher who cannot teach this competency can at least instruct the student to study it in other contexts. From the student's point of view, it is important to observe a different culture in order to know it better. It is about observing cultural patterns that occur in different areas when in contact with another culture (for example, when travelling abroad or when watching a foreign film or other recordings). In particular, S. Ter-Minasova (2000) noted that "the term intercultural communication implies successful, effective communication of representatives of different cultures. Because language is the main and most developed means of human communication, the interconnection and interaction of language and culture are at the heart of intercultural communication". And further: "As a type of human activity language is a component of culture, which is defined as the totality of the results of human activity in different spheres of human life: industrial, social, spiritual.”

This article examines some peculiarities of a foreign language studying as a means of intercultural communication. The connection of culture and lan- 
guage becomes most noticeable when students encounter features of translation even into the very first foreign language lessons. At the very beginning of learning English, it turns out that two personal pronouns "ty" (Ukrainian) and " $v y$ " (Ukrainian) have one equivalent in English - "you", which already reflect the cultural characteristics of English-speaking countries. Further studying foreign languages has the opportunity not only to compare different languages, but also different cultures, to find common and different in them, to enrich your life experience. Not for nothing, S. G. Ter-Minasova (2000) notes: "Each lesson of a foreign language is a crossroads of cultures, this is the practice of intercultural communication because each foreign word reflects the foreign world and foreign culture: each word has an idea of the national consciousness (foreign again, if the word is foreign) the world" (p. 25). Without taking into account national cultural characteristics when learning a language, it is impossible to master the subject entirely. The concept of communicative intercultural competence is a universal phenomenon, regardless of place and time (Suprunov, 2017). This is a skill that is not acquired immediately, but over time and in the learning process, as well as knowledge of a foreign language develops in the process of learning it. It is difficult to get such a competency because it is acquired by observing cultural elements.

Without taking into account national cultural features, it is impossible to master the subject completely. The cultural differences have to make a difference in the interaction to qualify the process as intercultural communication. (Arasaratnam, 2013).

Any activity requires goal setting. Why is it necessary to learn a foreign language in the modern world, where there are gadgets with applications-translators? In light of modern trends, a foreign language is no longer an aim in itself for learning. The purpose of a foreign language lesson is to teach you how to communicate in another language, but "communication and culture are inseparable” (McQuail \& Windahl, 1993) as was noted more than once.

In some languages, there are words that denote certain phenomena of human life that are characteristic of all cultures but do not have equivalents in other languages. Untranslatable words are called the realities of the language (objects, national characteristics, historical facts that have no equivalents in other languages). In the English language, there are a lot of such "untranslatable" words and phrases.

"Closet music" This phrase is used to indicate music that you have to listen to alone because of the fear of being ridiculed. For example, if in appearance a brutal man loves Justin Bieber's work, he is unlikely to tell everyone around him.

"Bromance" (from brother and romance). This term can be explained in many languages, but the word itself is exclusively in English. The relationship between two close friends is called bromance. It is important to note that the relationship should be friendly.

"Stage - phoning" (literally - staging call). Imagine a guy who, having seen a beautiful girl on a bench, decided to imitate a telephone conversation. And he casually mentioned his Mercedes and a house in Miami. This is the same "stage call”. 
"Brandalism" (from brand and vandalism). A situation in which city facades are hidden behind ugly banner ads is called brandalism.

"Football widow". This expression is used to refer to a woman whose husband is "overly carried away" by something. For example, during the World Cup, it seems that all men are simply lost to the world. Today this expression has varieties: the popular game World of Tanks has also made many women widows so that this expression can transform into "Tanks widow".

"Gobbledygook" Was it hard to read? That is the point! This word means too pompous, bureaucratic language, characteristic of official communications, legal documents. Some people intentionally use hard-to-understand words and sentences to seem more knowledgeable than they really are.

But, ignorance of certain expressions is only one side of the issue. A foreign language teacher should not only introduce his students to a set of lexical units and grammar rules but also show how to use them in a situation of real communication. Foreign language learners should see the goal of their efforts to learn another language, namely, learn to use it as an instrument of intercultural communication. Foreign language learners should see the goal of their efforts to learn another language, namely, learn to use it as an instrument of intercultural communication. The methodology of teaching foreign languages is based not only on linguistic facts but also on extralinguistic, which are necessary for the communication process. Speaking a language, representatives of different cultural communities cannot always adequately understand each other. The problem often lies in the divergence of cultures. As noted, "even native speakers of the same language can act as representatives of different cultures or subcultures. They also may not fully understand each other" (Makshantceva, 2001). Any person sees the world within a certain cultural framework. But these cultural frameworks (norms), as a rule, are not recognised by the individual, because most often they are so inherent in him that they form part of his personality. Awareness of the norms of behaviour and thinking of one's own culture is possible only when there are contacts with people who are guided by other cultural norms in their behaviour.

People to one degree or another expand the boundaries of their cultural horizon, visiting other countries, studying foreign languages, reading foreign literature, talking with foreigners. However, this interaction can cause discomfort or even lead to conflicts that are often difficult to explain. The mechanisms of behaviour and evaluations that worked until communication was carried out within the framework of one culture begin to fail; communication becomes difficult. This causes uncertainty, loss of internal stability, incorrect interpretations of partner behaviour, and misunderstanding of each other. Therefore, if until now a person has not noticed or realised the peculiarities of his behaviour, due to his cultural context, now these subconscious models of perception, emotional reactions, thinking, behaviour and assessments are becoming more obvious and subject to reflection, accounting and correction concerning the partner on communication. The behaviour of people belonging to other cultures is not at all unpredictable, and it can be studied and predicted. The study of other cultures, their characteristics, patterns of their functioning and development enriches a person, 
transforms his attitude towards the world and other people, and can drastically change his attitude to life situations. For successful communication, mastering only the language code is not enough. It is also necessary to master the sociocultural code of the community in the language of which communication is carried out, with the knowledge and ideas that are stored in its "cognitive base" - the totality of knowledge and ideas common to all members of this community.

In English, there are a large number of lexical units that may not be fully understood by a Ukrainian-speaking student who is unfamiliar with the national cultural specifics of English-speaking countries. However, even a flawless choice of an analogue of the Ukrainian word will not provide an understanding of speech in general. Of course, the relationship of language and culture is most clearly manifested in vocabulary: methods of nomination, words with a nationalcultural component of meaning (for example, equivalent, background vocabulary), etc. Vocabulary reflects reality, responds to changes in the social, material and cultural life of the people. In the lessons of a foreign language, it seems necessary to pay special attention of students to the mismatch of the translation of lexical units from one language to another.

However, it is worth paying attention to other features of foreign-language and foreign-cultural communication. So, English speech stamps can cause problems for students. No wonder the speech stamp is defined as "a means of speech, deposited in the collective consciousness of speakers of a given language as a stable, "ready to use" and therefore the most "convenient" sign for expressing a certain linguistic content. For example, in oral speech "Look here" is not translated literally, but used to attract the listener's attention: "Listen"! Also "I see" is used in the conversation to say that someone has understood something, which translates as "I got it." The phrase "That will do" means "Enough" (no more is needed or desirable). In the Ukrainian language, there are such introductory expressions as " $Z$ odnoho boku" (On the one side"), " $Z$ inshoho boku" (On the other side"). Their English equivalents are "On the one hand", "On the other hand". Such speech stamps reflect the prevailing linguistic traditions. Students are desirable to understand their meaning without literal translation into their native language. The interconnection of culture and language is clearly manifested in phraseological units.

Many proverbs, sayings convey specific national features; the imagery contained in them reflects the history of the people, its customs, traditions, unique character traits, etc.

"A rolling stone gathers no moss" - this proverb translates as "rolling stone will not be overgrown by moss". It is wrong to assume that the meaning of this proverb is the same as that of the proverb: "No water flows under the underlying stone" (Ukrainian variant). But if our proverb forces people to move, motivating them to work, to make money, then the English version of "A rolling stone gathers no moss", on the contrary, causes a person to stop, to acquire a fortune, a house and material goods - "moss". And if a person rolls like a stone to wander around the world, then he will waste all his wealth.

"Do not make a mountain out of an anthill" - it would seem impossible to combine information about the mountain and the anthill, but the proverbs and 
sayings in English do not cease to amaze! The translation is simple enough: "Don't make a mountain worse," which means: "Don't exaggerate.” By the way, there is also a version of this proverb in the Ukrainian language: "Don't make flies out of an elephant".

"The modern concept of foreign language education is based on the integrated learning of the language and culture of the countries being taught, and on the use of the national component, based on knowledge of the native country, the history of its people, its traditions, customs, etc., that is, the dialogue of native and foreign culture. The main purpose of such education is to teach language through culture and culture through language.” (Filonova, 2012).

In the English language, there is a large number of phraseological units of literary origin. L. Carroll in the book "Alice in Wonderland" popularised the expression "mad as a hatter" (not in one's mind, a lunatic as a hatter), which has historical justification - it was believed that the hatters were losing their mind using the mercury when felt processing.

In foreign language classes, students not only learn the culture and traditions of other countries but also learn to put this knowledge into practice. A foreign language is an instrument of intercultural communication, so it is important to allow students to use it in action.

Intercultural communication - "communication of different cultures and languages speakers” (Ter-Minasova, 2000). It can be either direct (in person) or indirect (media, books, the Internet, etc.). It can be everyday (for example, during tourist trips) as well as professional orientation (when communicating with colleagues, when relying on foreign materials in scientific work, etc.). While previously the emphasis was on the translation of highly specialised texts with a dictionary (and a specialist with higher education usually wrote in questionnaires "I translate with a dictionary"), now the emphasis has shifted to the study of a foreign language as a means of communication between representatives of different countries. The task of practical learning of language as a means of intercultural communication is achieved in foreign language lessons in higher education establishments through a variety of activities. Thus, students can be offered discussions in a foreign language, round tables, business games and brainstorming, participation in international conferences, communication with their and future colleagues from other countries, etc. The main thing is to create a real communicative situation when teaching a foreign language, to connect the study of the subject with real life, to create the right motivation for learning with a practically oriented aim.

Young scientists will learn that a scientific presentation is replete with polite cliché phrases, and in English, they are doubly polite. When addressing the audience, you should say "Dear colleagues"; starting the report, you can use "Can I have your attention, please?" and when answering a question, thank for attention to the report not just "Thank you for the question", but, for example, "We are grateful for your kindest attention to the report". The emergence of a possible discussion in a foreign language is an excellent bonus for the participants of the conference. Thus, all that the students have previously studied in the lesson worked out during the exercise, gets the sense, the motivation for 
further improvement of the foreign language appears. Foreign language does look to be an instrument of intercultural communication.

It is important for us to carefully monitor what is happening in the language, if only in order to be able to answer students' questions about innovations, and also to modify traditional rules in time. Changes in the vocabulary of the English language occur in the most noticeable way. New words appear in the language, existing ones get new meanings, and some go completely out of use. If we analyse modern media in English (newspapers, magazines, radio / TV shows, films), we can come to a conclusion about the following sources of influence on modern English: new technologies; modern ways of communication; slang of youth and adolescents; global issues; global culture; other foreign languages. It should be noted that 20 years ago no one knew what "blog" means, but when Internet users started writing "weblogs online", the phrase was soon shortened to "blog" and the person writing was called "blogger". Nowadays, Internet users are constantly warned about the dangers of "phishing" (a criminal attempt to use someone else's credit card or other information of the owner). "Phishing" resembles another English word - "fishing", which means "hooking". The section on the website of the British news agency BBC "BBC News magazine" studies current trends in the English language, publishes lists of the most frequently used words of recent years, as well as "words of the year", which have become especially popular. The list of frequently used and popular words of recent years includes: "Google”, "dotcom”, "texting”, "twitter”, "emoticon”.

In addition, reading in English itself is the most natural and sure way to advance in the language. For example, there is one of the world's largest television and radio corporations $\mathrm{BBC}$ News. The main content is video and audio products. The BBC News site is a great source of international news. Correspondents work all over the world, so you can always find detailed information and analytics on the events of not only the UK and Europe, but also of other countries at the BBC. News is sorted into thematic sections - World, Business, Sport, Tech, Science, Stories, Entertainment and Arts, Special Reports, Explainers, Reality Check and a special section, in which readers can share their opinion, take part in a survey or give journalists an idea for stories. The use of such materials provides an excellent opportunity to immerse the student in the language and culture of other countries.

It is important for us to carefully monitor what is happening in the language, if only in order to be able to answer students' questions about innovations, and also to modify traditional rules in time.

\section{Conclusions}

This article allowed to touch only on some aspects of the interaction of language and culture in the lessons of a foreign language. It is necessary to approach the study of the language not as a faceless collection of rules and exceptions, but as a living means of communicating with other people. Fluency in a foreign language is achieved not through the knowledge of grammar, vocabulary, pronunciation skills or the ability to translate, but through knowledge of 
someone else's culture. Being an instrument of intercultural communication, language is closely and inextricably linked with the national cultural characteristics of the society in which it operates. Various techniques and methods for introducing students to the culture of other countries, the use of a foreign language in a real situation of communication motivates students to study the subject successfully. In the process of teaching, the focus is on the need to practice the use of a foreign language as a means of intercultural communication and the process of teaching a foreign language should be reviewed and optimised taking into account the development trends of intercultural communication in a multicultural world.

\section{References}

Arasaratnam, L. A. (2013). Intercultural Communication Competence. In A. Kurylo (Ed.), Intercultural Communication: Representation and Construction of Culture (Ch. 3, pp. 47-68). SAGE Publications. http://dx.doi.org/10.4135/9781544304106. n3 [in English].

Filonova, V. (2012). Mizhkulturna komunikatsiia ta vyvchennia inozemnykh mov [Intercultural communication and foreign language learning]. Bulletin Taras Shevchenko National University of Kyiv. Oriental languages and literatures, 18, 41-43 [in Ukrainian].

Gitimu, P. N. (2005). Intercultural Communication: Its Importance to Various Careers Fields and Perspective by Various Authors. Online Journal for Workforce and Education and Development, 1(2). https://opensiuc.lib.siu.edu/ojwed/vol1/iss2/4/ [in English].

Holubenko, N. I. (2015). Osoblyvosti vidtvorennia u perekladi movnykh reprezentatsii kontseptiv amerykanskoho Pivdnia "Pivdenna Ledi i Pivdennyi Dzhentlmen" [Peculiarities of reproduction in the translation of linguistic representations of the concepts of the American South "South Lady and Southern Gentleman"]. In A. V. Korolova (Ed.), Problemy zistavnoi semantyky [Problems of comparative semantics]. Vydavnychyi tsentr KNLU [in Ukrainian].

Makshantceva, N.V. (2001). Mezhkulturnaia kommunikatciia v protcesse izucheniia iazyka [Intercultural communication in the process of learning a language]. In W. Susmann, \& A. Frolov (Eds.), Mezhkulturnaia kommunikatciia [Intercultural Communication]. Dekom [in Russian].

Maslova, V. A. (2004). Kognitivnaia lingvistika [Cognitive linguistics]. TetraSistems [in Russian].

McQuail, D., \& Windahl, S. (1993). Communication models for the study of mass communications. Longman [in English].

Suprunov, S. E. (2017). Ot mezhkulturnoi kommunikatcii k mezhkulturnomu obucheniiu [From intercultural communication to intercultural learning]. Molodoi uchenyi, 11(145), 490-493 [in Russian].

Ter-Minasova, S. G. (2000). Iazyk i mezhkulturnaia kommunikatciia [Language and intercultural communication]. Slovo [in Russian]. 


\title{
ВЗАЄМОДІЯ МОВИ ТА КУЛЬТУРИ ПРИ ВИВЧЕННІ ІНОЗЕМНИХ МОВ У ЗАКЛАДАХ ВИЩОЇ ОСВІТИ
}

\author{
Сарновська Наталія Іванівна
}

Викладач,

ORCID:0000-0001-7278-5183,nat_sarnovskaya@ukr.net,

Київський національний університет культури і мистецтв, Київ, Україна

Мета статті - розглянути та продемонструвати особливості вивчення іноземної мови як засобу міжкультурної комунікації, довести, що для ефективного спілкування іноземною мовою необхідно не лише володіти цією мовою на достатньому рівні, але й бути знайомим із культурою її носіїв. Професійна компетентність фахівців нової формації вимагає наявності знань, умінь, навичок для встановлення діалогу та взаєморозуміння на високому професійному рівні, а отже, налагодження діалогу між культурами; толерантного ставлення до мовних та культурних відмінностей співрозмовника, непорозумінь, яких не уникнути під час спілкування з представниками іншої культури. Методи дослідження включають вивчення, аналіз та узагальнення з метою продемонструвати докази нерозривного зв’язку культури та мови при вивченні іноземних мов. Наукова новизна полягає в тому, щоб показати нові особливості англійської мови як іноземної (оскільки нові технології, сучасні способи спілкування, сленг, всесвітні проблеми, глобальна культура, інші іноземні мови призводять до лексико-семантичних змін словникового складу мови і його поновлення, про що свідчать приклади зі 3МI, які наведені у статті); продемонструвати ключові поняття культурної грамотності і розглянути теоретичні і практичні питання, що мають відношення до підвищення культурної грамотності при вивченні іноземних мов. Автор вважає, що при вивченні іноземної мови необхідно приділяти виняткову увагу характерним особливостям сучасної лексики, пов'язаним зі зростаючою роллю інтернету та інших інформаційних технологій, і пропонує методи розвитку комунікативної компетентності з урахуванням піднесення міжкультурної комунікації.

Висновки. Робота демонструє, що вільне володіння іноземною мовою досягається не завдяки знанням граматики, словниковому запасу, навичкам вимови чи вмінню перекладати, а завдяки пізнанню іноземної культури. В процесі навчання акцент робиться на необхідності практикувати використання іноземної мови як засобу міжкультурного спілкування. Процес навчання іноземній мові повинен бути переглянутий і оптимізований з урахуванням тенденцій розвитку міжкультурної комунікації в умовах полікультурного світу.

Ключові слова: вивчення іноземної мови, іноземна мова у ВНЗ, англійська мова, культура, міжкультурна комунікація, культурна грамотність. 


\title{
ВЗАИМОДЕЙСТВИЕ ЯЗЫКА И КУЛЬТУРЫ ПРИ ИЗУЧЕНИИ ИНОСТРАННЫХ ЯЗЫКОВ В ВЫСШИХ УЧЕБНЫХ ЗАВЕДЕНИЯХ
}

\author{
Сарновская Наталия Ивановна
}

Преподаватель, ORCID: 0000-0001-7278-5183,nat_sarnovskaya@ukr.net, Киевский национальный университет культуры и искусств, Киев, Украина

Цель статьи - рассмотреть и продемонстрировать особенности изучения иностранного языка как средства межкультурного общения, доказать, что для эффективного общения на иностранном языке необходимо не только владеть этим языком на достаточном уровне, но и быть знакомым с культурой его носителей. Профессиональная компетентность специалистов новой формации требует наличия знаний, умений, навыков для установления диалога и взаимопонимания на высоком профессиональном уровне и, следовательно, налаживания диалога между культурами; толерантного отношения к языковым и культурным различиям собеседника, недопониманию, которого не избежать во время общения с представителями другой культуры. Методы исследования включают изучение, анализ и обобщение с целью демонстрации свидетельства неразрывной связи культуры и языка при изучении иностранных языков. Научная новизна состоит в том, чтобы показать новые особенности английского языка как иностранного (поскольку новые технологии, современные способы общения, сленг, всемирные проблемы, глобальная культура, другие иностранные языки приводят к лексико-семантическим изменениям словарного состава языка и его пополнению, о чем свидетельствуют примеры из СМИ, приведенные в статье); продемонстрировать ключевые понятия культурной грамотности и рассмотреть теоретические и практические вопросы, имеющие отношение к повышению культурной грамотности при изучении иностранных языков. Автор считает, что при изучении иностранного языка необходимо уделять исключительное внимание характерным особенностям современной лексики, связанным с возрастающей ролью интернета и других информационных технологий, и предлагает методы развития коммуникативной компетентности с учетом совершенствования межкультурной коммуникации.

Выводы. Работа демонстрирует, что свободное владение иностранным языком достигается не благодаря знаниям грамматики, словарному запасу, навыкам произношения или умению переводить, а благодаря познанию иностранной культуры. В процессе обучения акцент делается на необходимости практиковать использование иностранного языка как средства межкультурного общения. Процесс обучения иностранному языку должен быть пересмотрен и оптимизирован с учетом тенденций развития межкультурной коммуникации в условиях поликультурного мира.

Ключевые слова: изучение иностранного языка, иностранный язык в ВУЗе, английский язык, культура, межкультурная коммуникация, культурная грамотность. 